\title{
GCU
}

Glasgow Caledonian

University

University for the Common Good

\section{Potential of implementing the low concentration photovoltaic systems in the United Kingdom}

Abu Bakar, Siti Hawa Binti ; Muhammad Sukki, Firdaus; Freier, Daria; Ramirez-Iniguez, Roberto; Mallick, Tapas Kumar ; Munir, Abu Bakar ; Yasin, Siti Rajar Mohd ; Abu Bakar, Siti Sarah; Bani, Nurul Aini; Muhtazaruddin, Mohd Nabil; Mas'ud, Abdullahi Abubakar

Published in:

International Journal of Electrical and Computer Engineering (IJECE)

DOI:

10.11591/ijece.v7i3.pp1398-1405

Publication date:

2017

Document Version

Publisher's PDF, also known as Version of record

Link to publication in ResearchOnline

Citation for published version (Harvard):

Abu Bakar, SHB, Muhammad Sukki, F, Freier, D, Ramirez-Iniguez, R, Mallick, TK, Munir, AB, Yasin, SRM, Abu Bakar, SS, Bani, NA, Muhtazaruddin, MN \& Mas'ud, AA 2017, 'Potential of implementing the low concentration photovoltaic systems in the United Kingdom', International Journal of Electrical and Computer Engineering (IJECE), vol. 7, no. 3, pp. 1398-1405. https://doi.org/10.11591/ijece.v7i3.pp1398-1405

\section{General rights}

Copyright and moral rights for the publications made accessible in the public portal are retained by the authors and/or other copyright owners and it is a condition of accessing publications that users recognise and abide by the legal requirements associated with these rights.

Take down policy

If you believe that this document breaches copyright please view our takedown policy at https://edshare.gcu.ac.uk/id/eprint/5179 for details of how to contact us. 


\title{
Potential of Implementing the Low Concentration Photovoltaic Systems in the United Kingdom
}

\author{
Siti Hawa Abu-Bakar' ${ }^{1}$, Firdaus Muhammad-Sukki², Daria Freier ${ }^{3}$, Roberto Ramirez-Iniguez ${ }^{4}$, \\ Tapas Kumar Mallick ${ }^{5}$, Abu Bakar Munir ${ }^{6}$, Siti Hajar Mohd Yasin ${ }^{7}$, Abdullahi Abubakar Mas'ud ${ }^{8}$, \\ Siti Sarah Abu-Bakar', Nurul Aini Bani ${ }^{10}$, Mohd Nabil Muhtazaruddin ${ }^{11}$ \\ ${ }^{1,3,4}$ School of Engineering \& Built Environment, Glasgow Caledonian University, Glasgow, United Kingdom \\ ${ }^{1}$ Universiti Kuala Lumpur British Malaysian Institute, Gombak, Selangor, Malaysia \\ ${ }^{2}$ School of Engineering, Robert Gordon University, Aberdeen, Scotland, United Kingdom \\ ${ }^{5}$ Environment and Sustainability Institute, University of Exeter, Penryn, Cornwall, United Kingdom \\ ${ }^{6}$ Faculty of Law, University of Malaya, Kuala Lumpur, Malaysia \\ ${ }^{6}$ University of Malaya Malaysian Centre of Regulatory Studies (UMCoRS), Kuala Lumpur, Malaysia \\ ${ }^{7}$ Faculty of Law, Universiti Teknologi MARA, Shah Alam, Malaysia \\ ${ }^{8}$ Department of Electrical and Electronic Engineering Technology, Jubail Industrial College, Saudi Arabia \\ ${ }^{9}$ The Dickson Poon School of Law, King's College London, Strand, London, WC2R 2LS, United Kingdom \\ ${ }^{10,11}$ UTM Razak School of Engineering and Advanced Technology, Universiti Teknologi Malaysia, \\ Kuala Lumpur, Malaysia
}

\begin{tabular}{|c|c|}
\hline Article Info & ABSTRACT \\
\hline Article history: & This paper discusses the prospect of integrating a novel type of low \\
\hline Received Jan 24, 2017 & $\begin{array}{l}\text { concentration photovoltaic (LCPV) design known as the rotationally } \\
\text { asymmetrical compound parabolic concentrator (RACPC) in a building in the }\end{array}$ \\
\hline Revised Apr 5, 2017 & United Kingdom. This is done by proposing a number of building integration \\
\hline Accepted May 10, 2017 & $\begin{array}{l}\text { designs to create a zero carbon building. A cost reduction analysis of } \\
\text { installing the LCPV systems in the country is also presented. It was found }\end{array}$ \\
\hline Keyword: & $\begin{array}{l}\text { that an RACPC design could reduce the LCPV module's manufacturing cost } \\
\text { by } 31.75 \% \text { and the LCPV module's cost per unit power output by } 33.87 \% \\
\text { when compared with the conventional PV module. }\end{array}$ \\
\hline
\end{tabular}

Photovoltaic system

Low concentration

Photovoltaic

Rotationally asymmetrical

Compound parabolic

Copyright $@ 2017$ Institute of Advanced Engineering and Science.

Concentrator

All rights reserved.

\section{Corresponding Author:}

Siti Hawa Abu-Bakar,

Universiti Kuala Lumpur British Malaysian Institute,

Batu 8, Jalan Sungai Pusu, 53100, Gombak, Selangor, Malaysia.

Email: hawa012@gmail.com

\section{INTRODUCTION}

The building sector is one of the largest energy consumers. The Intergovernmental Panel on Climate Change (IPCC) in its Climate Change 2014 report states that this sector 'is responsible for $46 \%$ of the final natural gas consumption, $76 \%$ of combustible renewables and waste, $52 \%$ of electricity use, and $51 \%$ of heat' [1]. It is therefore crucial to meet the energy demand in the building sector, which is expected to increase every year [2]. The European Commission (EC) stated that the building sector has the largest potential in terms of energy savings and reduction of greenhouse gas (GHG) emissions in the future [3]. This can be achieved by implementing the Zero Carbon Building (ZCB), a concept in which a building is capable of independently generating energy for its own consumption and in which it must also be energy efficient to minimise the energy requirements and energy loss [4],[5]. A solar photovoltaic (PV) system has the potential to be implemented in a ZCB construction. In recent years, the installation of solar PV systems has changed 
from simply being mounted on a roof or facade (known as the building applied photovoltaic (BAPV) system) to replacing part of or the entire building structure itself (which is widely known as the building integrated photovoltaic (BIPV) system) to create semi transparent windows, PV skylights, exterior cladding panels etc. [4],[6].

Although there has been an oversupply and declining prices of PV modules, the overall installation cost of a PV system in many countries is still considered very expensive. The PV module contributed approximately $45 \%$ of the total cost of installation [7]. The PV material contributes to approximately 73\% [8] of the cost of the PV module. To reduce the usage of expensive PV material without compromising the module's performance, a number of researchers have suggested to incorporate a solar concentrator, typically a low concentration photovoltaic (LCPV) device in the PV module [9]-[14].

A novel type of an LCPV device known as the rotationally asymmetrical compound parabolic concentrator (RACPC) has been proposed for use in building integration (see Figure 1). The steps to produce the RACPC have been discussed in detail in Ref [15]. One specific design was fabricated and tested indoors and the results indicated that the specific RACPC could increase the maximum power output by $3.33 \mathrm{x}$ when compared with a bare cell [16].

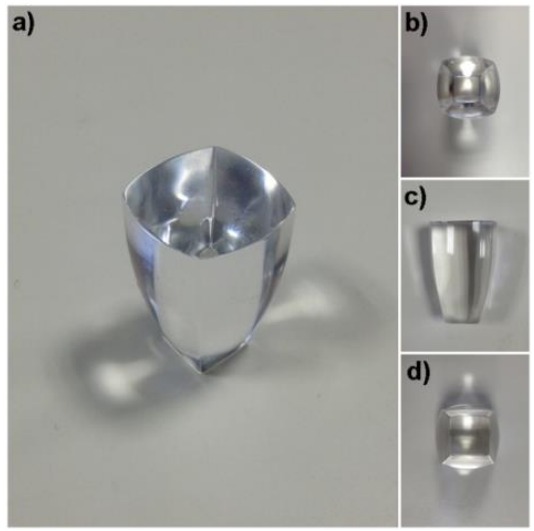

Figure 1. The RACPC prototype fabricated for experimental purposes, (a) the isometric view; (b) the top view; (c) the side view, and (d) the bottom view of the concentrator

\section{TOWARDS THE CREATION OF ZERO CARBON BUILDING IN THE UK}

In 2002, the EC approved the Energy Performance of Buildings Directive (EPBD), which officially started in January 2003 [17]. This Directive was aimed at improving the energy efficiency of the buildings within the European Union (EU) through various cost-effective measures [17]. This Directive also catalysed the United Kingdom (UK) government to implement a series of legislations and programmes in the subsequent years that are closely aligned with this Directive. It is not the aim of this paper to provide a detailed description about each legislation and programme related to solar PV, since it has been covered in many literature, e.g. in Refs [18]-[21].

The Zero Carbon Building (ZCB) policy was first announced in late 2006 by the UK government, with the target of making all new homes 'zero carbon' from 2016 onwards [22]. In order for a home to be qualified as a ZCB, there are three major conditions that need to be met, which are [22],[23]:

1. The building's fabric must fulfil the Fabric Energy Efficiency Standard (FEES), i.e. it must be very well insulated and air-tight to minimise the energy demand in the building.

2. Any $\mathrm{CO}_{2}$ emissions after taking into account the heating, cooling, lighting and ventilation, must not exceed the 'Carbon Compliance' limit established for the ZCB, e.g. 10,11 and $14 \mathrm{~kg} \mathrm{CO} / \mathrm{m}^{2} /$ year for a detached house, an attached house and a low rise apartment respectively. This means that any building must generate enough energy for its own consumption, which can be achieved through the implementation of low carbon technology such as solar PV and solar thermal systems.

3. Any remaining $\mathrm{CO}_{2}$ emissions (after meeting requirements 1 and 2) must be reduced to zero. There are two ways to achieve this; either by 'over performing' on requirements 1 and 2 , or by investing in 'Allowable Solutions'.

In mid 2015 however, the ZCB policy was scrapped by the UK government [24]. Many groups expressed their dissatisfaction about this issue [25]. Nevertheless, the creation of a ZCB policy is still being pursuit by many parties, i.e. developers, energy leaders, environmentalists etc. [25]. 


\section{POTENTIAL OF LCPV INTEGRATION IN THE BUILDING}

The ZCB provides an interesting platform for the LCPV design to be implemented in the UK, mainly as an alternative to the conventional solar PV system. It has been indicated in Refs [15],[16] that an LCPV system could generate not only electricity, but it has the capabilities to provide natural illumination into the building, to provide space heating and hot water generation or ventilation (depending on the heat extraction method to utilise the co-generated heat from the photovoltaic effect) which further reduces the energy consumption in a building. The RACPC-PV module can be implemented in a number of ways and could replace the windows, rooftops and building facades.

To maximise its potential, a number of ways of interconnecting the concentrators in the module are proposed. The most typical installation of a traditional solar PV is on the rooftop. The LCPV module can be integrated into a new building, with configurations shown in Figures 2 and 3. In Figure 2, the array of concentrators is placed on top of a glass substrate and the thin layer of material that holds the concentrators together replaces the front glass substrate as the front cover of the module. The LCPV module is inclined at the optimum tilt angle to capture as much sun energy as possible. The distance between the concentrators can be designed either to maximise the electricity generation (by reducing the distance between the concentrators in an array) or can be arranged in such a way that it can allow more natural light to illuminate the building interior. This LCPC design also acts as a skylight. This arrangement is suitable for a typical residential building.

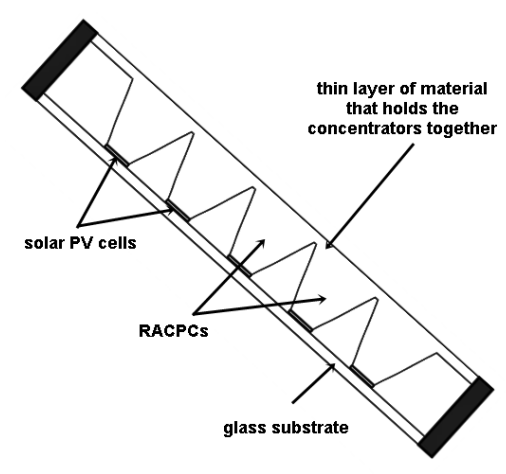

Figure 2. Proposed configuration for installing the LCPV module on an inclined rooftop

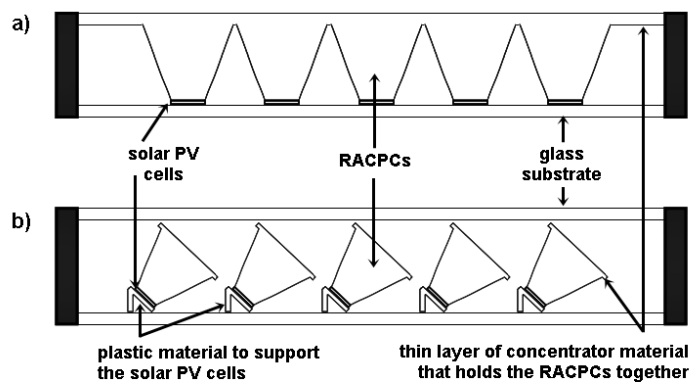

Figure 3. Proposed configuration for installing the LCPV module on horizontal surfaces, e.g. a flat rooftop

For a horizontal rooftop - normally for commercial and industrial buildings, different arrangements are proposed, as illustrated in Figure 3. The first configuration involves arranging the exit aperture of the concentrators in parallel with the horizontal rooftop, as indicated in Figure 3(a). However, specifically in a country at a higher latitude such as the UK, this configuration will not yield optimum electrical output. This is because the sun light will already be outside the half-acceptance angle of the concentrator (due to the seasonal variations of sun path). Because of this, this design is more suitable for countries that lie within the equatorial belt. An alternative arrangement involves tilting the concentrator at the optimum angle in the module design itself, as illustrated in Figure 3(b). The solar cells will be soldered on a layer of plastic material, and an array of concentrators (in rows of $N$ ) can then be mounted on the solar cells. This enables this LCPV design to maximise the collection of sunlight for electricity generation throughout the year. 
For vertical integration (e.g. in a building facade or windows), two LCPV arrangements are proposed, either the concentrators are tilted at optimum angle or lay parallel to the building facade, as presented in Figures 4(a) and (b) respectively. Comparing these two designs, the former arrangement is more desirable than the latter mainly to have an optimum tilt angle with respect to the sun, which will ensure maximum electricity generation from the LCPV module. It is possible to say that these arrangements offer an added advantage to new building structures, when they employ transparent/semi transparent facades to maximise the natural illumination. The LCPV module can be an excellent substitute to conventional PV systems in these situations.

Despite this advantage, the assembly process of producing a tilted concentrator in the module could be challenging. Therefore, more extensive research needs to be carried out with respect to the assembly process and the building integration using the LCPV module.



Figure 4. Proposed configuration for installing the LCPV module on a vertical surface, e.g. a building facade and a window

\section{COST REDUCTION ADVANTAGE OF USING THE LCPV SYSTEM}

It has been indicated earlier that the aim of pursuing the LCPV design is to reduce the installation cost of a solar PV system. It is therefore important to predict theoretically the cost reduction that can be achieved by incorporating the RACPC design to create an LCPV module. According to Sarmah et al. [26], the typical conventional BIPV module is made of silicon solar cells laminated between two thick glasses. Therefore, the cost comparison of the LCPV module should be compared with the commercially available glass-laminated PV module. To simplify the analysis, other costs such as inverter, external wiring from the modules to the inverter and overall PV system installation cost are not considered in this analysis. The concentrating and non-concentrating PV modules used for the calculation here have dimensions of $111 \mathrm{~cm} \mathrm{x}$ $85 \mathrm{~cm} \mathrm{x} 4 \mathrm{~cm}$. The breakdown cost for a glass-laminated conventional PV module and the LCPV module that incorporates the RACPC design are presented in Table 1. From the table, it can be seen that the RACPC-PV module could reduce the manufacturing cost by $31.75 \%$ when compared with a traditional solar PV module.

Table 1. Theoretical cost of fabricating a $0.94 \mathrm{~m}^{2}$ module (in $£$ )

\begin{tabular}{ccc}
\hline Item & Conventional solar PV module & RACPC-PV module \\
\hline PV[28] & 30.72 & 7.59 \\
Concentrator [29-31] & 0.00 & 11.10 \\
Glass [32] & 5.28 & 2.64 \\
Encapsulation [33-36] & 3.62 & 4.82 \\
Frame [37,38] & 3.18 & 3.18 \\
Wiring [6,39] & 1.29 & 0.76 \\
Labour [40] & 6.17 & 4.21 \\
Total & 50.26 & 34.30 \\
Cost reduction (\%) & & 31.75 \\
\hline
\end{tabular}

To determine the price per unit watt of the RACPC-PV module, the cost to produce a $1 \mathrm{kWp}$ panel is estimated and presented in Table 2. Based on the datasheet from Solar Capture Technologies [27] and the 
experiments carried out in Ref [16], a $0.94 \mathrm{~m}^{2}$ of conventional PV module and the RACPC-PV module could produce $89.63 \mathrm{~W}$ and $92.50 \mathrm{~W}$ under standard test conditions respectively. Therefore, in order to produce a 1 $\mathrm{kW}$ power output, these modules must cover an area of $10.48 \mathrm{~m}^{2}$ and $10.16 \mathrm{~m}^{2}$ correspondingly. By using the information in Table 1 , the cost to create the modules per $\mathrm{m}^{2}$ is estimated to be $£ 53.47$ for the traditional PV module and $£ 36.49$ for the RACPC-PV module. Therefore, the overall cost to produce a $1 \mathrm{kWp}$ panel is estimated to be $£ 560.81$ for the conventional PV panel and $£ 370.84$ for the RACPC-PV panel. The analysis shows that the RACPC could reduce the cost per unit power output from $£ 0.56 / \mathrm{W}$ to $£ 0.37 / \mathrm{W}$, a reduction of $33.87 \%$.

Table 2. Theoretical cost per unit power of a panel in (£/W)

\begin{tabular}{ccc}
\hline Item & Conventional PV panel & RACPC-PV panel \\
\hline Power $(\mathrm{kW})$ & 1.00 & 1.00 \\
Area covered $\left(\mathrm{m}^{2}\right)$ & 10.48 & 10.16 \\
Cost $\left(£ / \mathrm{m}^{2}\right)$ & 53.47 & 36.49 \\
Cost $(£ / \mathrm{W})$ & 0.56 & 0.37 \\
Cost reduction $(\%)$ & & 33.87 \\
\hline
\end{tabular}

The cost reduction obtained from implementing the LCPV system could attract other consumers (including architects, manufacturers, builders and end users) in implementing these designs into the building. Taking into account the UK's feed-in tariff and the green deal schemes, the consumer could further benefit from a lower installation cost, which translates into a higher annual return on investment and a shorter payback period [4],[20],[28].

\section{CONCLUSION}

The potential of implementing the LCPV system in the UK has been discussed in this paper. The ZCB policy aims at making all new homes to be 'zero carbon' from 2016. It has been discussed that one of the ways to meet the ZCB criteria is for the building to generate its own energy to meet its energy requirements e.g. from a solar PV system. The LCPV system could be a potential candidate as an alternative for the conventional solar PV system to be integrated in a building and some ways to integrate the LCPV designs, i.e. the RACPC-PV module, were presented as well. It was found that an RACPC design could reduce the LCPV module's manufacturing cost by $31.75 \%$ and the LCPV module's cost per unit power output by $33.87 \%$ when compared with the conventional PV module.

\section{ACKNOWLEDGEMENTS}

This project is funded by Glasgow Caledonian University (GCU), Scotland's Energy Technology Partnership (ETP), Majlis Amanah Rakyat (MARA), Malaysia, Ministry of Higher Education (MOHE), Malaysia and Universiti Teknologi Malaysia (UTM) (Research cost centre no. Q.K130000.2540.11H28). The authors would like to acknowledge the collaboration of AES Ltd. and its contribution to this project. Thanks are due to Mr Ian Baistow from Solar Capture Technologies Ltd, United Kingdom for providing the solar cells, Mr Antoine Y Messiou from UK Optical Plastics Limited, United Kingdom for fabricating the concentrators and Mr Mark Kragh from Off- Grid Europe, Germany for supplying the tabbing wire.

\section{REFERENCES}

[1] IPCC, "Climate Change 2014: Mitigation of Climate Change," Contribution of Working Group III to the Fifth Assessment Report of the Intergovernmental Panel on Climate Change. Cambridge University Press, Cambridge, United Kingdom and New York, NY, USA, 2014.

[2] P. Lombard L., et al., "A review on buildings energy consumption information," Energy Build, vol. 40, pp. 394-8, 2008.

[3] Grözinger J., et al., "Overview of Member States Information on NZEBs Background Paper - Final Report," Germany, 2014.

[4] M. Sukki F., "Optimised Solar Concentrator for the Solar Photonic Optoelectronic Transformer System," PhD Thesis, Glasgow Caledonian University, United Kingdom, 2013.

[5] Mallick T. K., "Solar Energy Research: Challenges and Opportunities," MSc SES Semin. Day, Edinburgh, 2011.

[6] Sarmah N., "Design and Performance Evaluation of a Low Concentrating Line-axis Dielectric Photovoltaic System," PhD Thesis, Heriot-Watt University, United Kingdom, 2012. 
[7] IEA-PVPS, "Trends 2014 in Photovoltaic Applications: Survey Report of Selected IEA Countries between 1992 and 2013," 2014.

[8] Goodrich A., et al., "A wafer-based monocrystalline silicon photovoltaics road map: Utilizing known technology improvement opportunities for further reductions in manufacturing costs," Sol Energy Mater Sol Cells, vol. 114, pp. $110-35,2013$.

[9] Sellami N. and Mallick T. K., "Optical characterisation and optimisation of a static Window Integrated Concentrating Photovoltaic system," Sol Energy, vol. 91, pp. 273-82, 2013.

[10] Mammo E. D., et al., "Performance analysis of a reflective 3D crossed compound parabolic concentrating photovoltaic system for building façade integration," Prog Photovoltaics Res Appl, vol. 21, pp. 1095-103, 2013.

[11] M. Sukki F., et al., "Mirror symmetrical dielectric totally internally reflecting concentrator for building integrated photovoltaic systems," Appl Energy, vol. 113, pp. 32-40, 2014.

[12] Sarmah N., et al., "Evaluation and optimization of the optical performance of low-concentrating dielectric compound parabolic concentrator using ray-tracing methods," Appl Opt, vol. 50, pp. 3303-10, 2011.

[13] Mallick T. K., et al., "Power losses in an asymmetric compound parabolic photovoltaic concentrator," Sol Energy Mater Sol Cells, vol. 91, pp. 1137-46, 2007.

[14] M. Sukki F., et al., "Optimised Dielectric Totally Internally Reflecting Concentrator for the Solar Photonic Optoelectronic Transformer System: Maximum Concentration Method," in Setchi R., et al., "Knowledge-Based Intell,” Inf. Eng. Syst. SE - 67, Springer Berlin Heidelberg, vol. 6279, pp. 633-41, 2010.

[15] A. Bakar S. H., et al., "Rotationally asymmetrical compound parabolic concentrator for concentrating photovoltaic applications," Appl Energy, vol. 136, pp. 363-72, 2014.

[16] A. Bakar S. H., et al., "Performance analysis of a novel rotationally asymmetrical compound parabolic concentrator," Appl Energy, vol. 154, pp. 221-31, 2015.

[17] BRE, "Energy Performance of Buildings Directive," 2006.

[18] A. Bakar S. H., et al., "Is Renewable Heat Incentive the future?" Renew Sustain Energy Rev, vol. 26, pp. 365-78, 2013.

[19] A. Bakar S. H., et al., "Financial analysis on the proposed renewable heat incentive for residential houses in the United Kingdom: A case study on the solar thermal system," Energy Policy, vol. 65, pp. 552-61, 2014.

[20] M. Sukki F., et al., "Revised feed-in tariff for solar photovoltaic in the United Kingdom: A cloudy future ahead?" Energy Policy, vol. 52, pp. 832-8, 2013.

[21] A. Bakar S. H., et al., "Renewable Heat Incentive for solar thermal systems in the United Kingdom: The next big thing?" 2012 IEEE Int. Conf. Power Energy, IEEE, pp. 626-31, 2012.

[22] UK Green Building Council, "New Build Homes," 2015.

[23] Zero Carbon Hub, "Zero Carbon Policy," 2015.

[24] H. M. Treasury, "Fixing the Foundations: Creating a more prosperous nation," 2015.

[25] Oldfield P., "UK scraps zero carbon homes plan," The Guardian UK, 2015.

[26] Sarmah N., et al., "Design, development and indoor performance analysis of a low concentrating dielectric photovoltaic module," Sol Energy, vol. 103, pp. 390-401, 2014.

[27] Solar Capture Technologies, "Cells," 2014.

[28] M. Sukki F, et al., "Solar photovoltaic in Malaysia: The way forward," Renew Sustain Energy Rev, vol. 16, pp. 5232-44, 2012.

\section{BIOGRAPHIES OF AUTHORS}

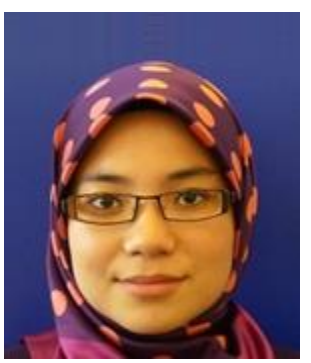

Dr Siti Hawa Abu-Bakar obtained her BEng in Information Systems Engineering from Imperial College, London in 2006 under the MARA scholarship. In 2007, she joined Prokhas Sdn. Bhd., a wholly-owned company under the Ministry of Finance Malaysia as the Executive Trainee. From 2008 onwards, she becomes a unit trust consultant for Public Mutual Bhd. In 2011, she was awarded studentships from GCU and Scotland's Energy Technology Partnership (ETP) to pursue her post graduate study in solar technology from which she obtained her PhD in 2016. Dr AbuBakar is an associate of the City and Guilds, London (ACGI). Her interests include solar PV, solar thermal, financial planning and investment analysis.

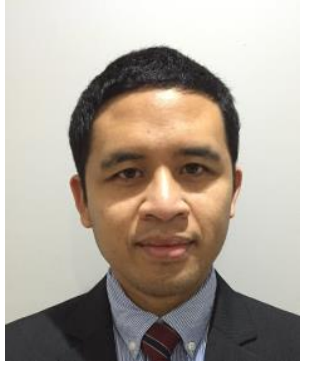

Dr Firdaus Muhammad-Sukki received his MEng degree in Electrical and Electronic Engineering from Imperial College, London in 2006 under the Yayasan TM scholarship. In 2009, he received studentship awards from Glasgow Caledonian University (GCU), Scottish Funding Council (SFC) and Yayasan TM to pursue his postgraduate study in Glasgow Caledonian University from which he obtained his $\mathrm{PhD}$ in 2013. His research interest is in solar energy, particularly in terms of designing optical solar concentrators to create a low cost solar photovoltaic system and renewable energy policies. He has a number of papers in high impact factor journals, as well as presenting in a number of conferences related to his area. Prior to joining the academia, he was a communication engineer in Malaysia's largest telecommunication company. He was in charge of the leased line servers for Malaysia's network and was involved in major projects related to the telecommunication while holding the post. 

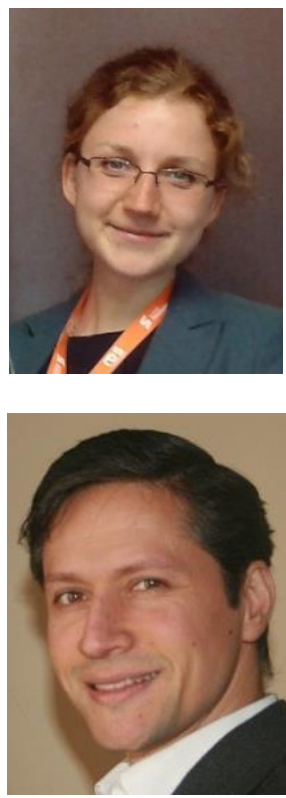

Dr Roberto Ramirez-Iniguez received a BEng degree in Electrical and Electronic Engineering from the Universidad Nacional Autónoma de México (UNAM) in 1996, and an MSc in Communications and Real-Time Electronic Systems from the University of Bradford in 1998. After obtaining his first degree he worked for a short period of time for Tektronix Mexico in the area of Tools and Business Units. In 1998 he started postgraduate studies at the University of Warwick from which he got his PhD in 2002. Shortly afterwards he started working as a researcher for Optical Antenna Solutions within the Communications and Signal Processing group in the Photonics and Communications Laboratory of Warwick University. He joined Glasgow Caledonian University in 2007 where he currently works as a senior lecturer within the School of Engineering and the Built Environment. Dr Ramirez-Iniguez has produced over 50 technical publications and has 3 patents under his name. He was awarded the IEE/Sir Henry Royce Award for excellence in research in 2003 and the IET WATW (2nd prize) in 2002. His research projects include: optical concentrators for solar photovoltaics and Building Integrated Photovoltaic (BIPV) Systems, optical front-ends for wireless infrared and visible light communications, optical antennas, and optical collimators/beam-shapers for illumination.

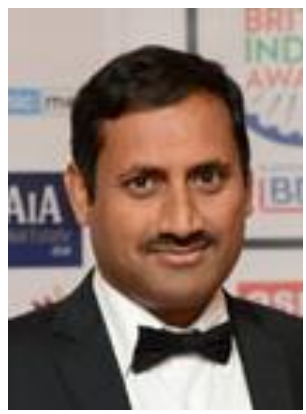

Professor Tapas Mallick received his MSc in Physics, MTech in Energy Sc \& Technology and $\mathrm{PhD}$ in solar energy engineering from Visva-Bharati (1996), Jadavpur University, India (1998) and University of Ulster, UK (2003) respectively. He has over sixteen years of research experience in solar energy technologies. He is currently the Chair Professor in Clean Technologies (Renewables) within the Environment and Sustainability Institute (ESI) and he is also Academic Lead of Renewable Energy at the College of Engineering, Mathematics and Physical Science, University of Exeter. In addition, he is Honarary Visiting Professor at the Department of Mechanical Engineering at Indian Institute of Technology, Madras, India. He has secured research funding ( $>£ 5.3 \mathrm{~m})$ as PI and Co-PI of various national, European, International and Industrial funders. He is author of over 190 research articles and holds two patents on solar technology, co-authors of two books and three book chapters. In addition to board members of numerous national/international conferences/seminars, Prof. Mallick is in the Editor-inChief of "Advances in Renewable Energy Journal" and recently appointed as Editor-in-Chief of Editorial Boards for Energy Sources in the Journal of 'Energies'. In 2013, Prof. Mallick's group has been awarded for "Outstanding Impact award in Sustainable Future" at the University of Exeter. Prof. Mallick successfully supervised $11 \mathrm{PhD}$ candidates to completion and currently supervisor of 12 $\mathrm{PhD}$ students.

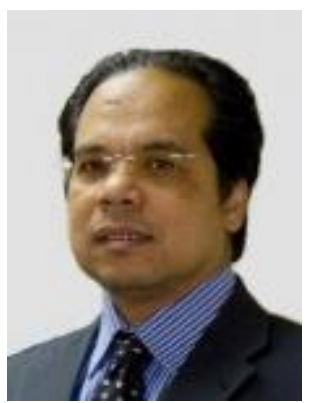

Professor Abu Bakar Munir, the former dean of the faculty of law at the University of Malaya, Malaysia is an internationally renowned scholar, expert and consultant on data protection law, ICT law and nanotechnology law and policy. He is also an associate fellow at the University of Malaya Malaysian Centre of Regulatory Studies and a visiting professor at several universities in Asia, Australia, New Zealand, the Middle East and Europe. Munir has been consulted by the governments and private entities in Malaysia and around the world. He was appointed as the adviser to the government of Malaysia on data protection law in 2007 and was instrumental in the crafting and the passing of the Personal Data Protection Act 2010. His other areas of interest are air and space law and renewable energy law and policy. 


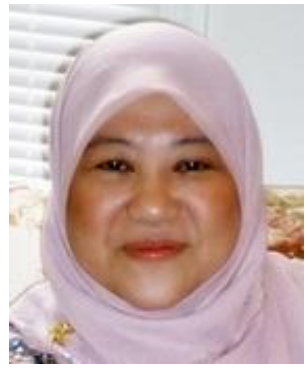

Associate Professor Siti Hajar Mohd Yasin (LLB, LLM) is an Associate Professor of Law, at the Faculty of Law, University Technology MARA, Shah Alam, Selangor D.E, Malaysia. She has been a full time lecturer at the university for more than twenty years, teaching various fields of laws. She graduated with a degree of Law, LLB (Hons) from the University of Malaya in 1987, received her post-graduate degree in Master in Comparative Laws (MCL) from the International Islamic University Malaysia (IIUM) in 1995. She also holds a post-graduate diploma in the Shariah Law and Practice from the IIUM. Associate Professor Mohd Yasin has researched, published and spoke at conferences, locally and internationally, and extensively. Her research interests include the Information and Communication Technology (ICT) Law, Nanotechnology Law, Constitutional Law and Environmental Law. She led a group of researchers from various universities in Malaysia in a research on Nanotechnology: Strategic, Policy and Regulatory challenges, funded by the Ministry of Higher Education of Malaysia under the Fundamental Research Grant Scheme (FRGS).
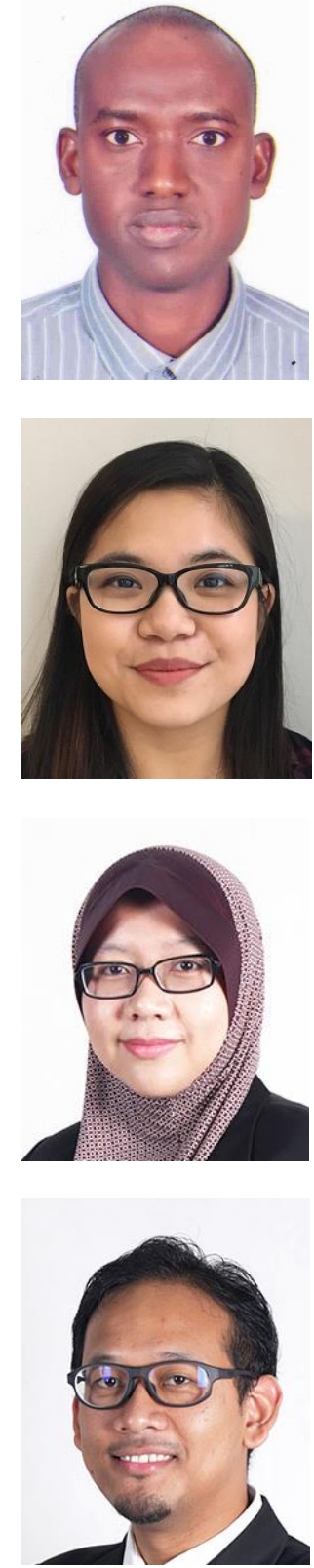

Dr Abdullahi Abubakar Mas'ud was born in Kano, Nigeria in 1975. He received his BEng (Hons) degree in Electrical Engineering in 1999 and his Msc in Electronics and Communication in 2006, both from Ahmadu Bello University, Zaria, Nigeria. He also received a PhD in High voltage Engineering in 2013 from the Glasgow Caledonian University, Scotland, UK. In 2002 he became an assistant lecturer in the Faculty of Engineering at the Ahmadu Bello University, Zaria, Nigeria. In 2013 he joined Jubail Industrial College, Saudi Arabia, and is currently an Assistant Professor in the Department of Electrical and Electronic Engineering. He has more than 10 years of teaching experience. His research interests lie in the fields of communication systems, renewable energy, high voltage partial discharge and nanotechnology. He has published numerous research papers in international conferences and journals. Dr Abdullahi A Mas'ud is a Member of the IET and a registered Engineer (COREN) Nigeria.

Ms Siti Sarah Abu Bakar received her LLB (Hons) Law degree from Queen Mary, University of London in 2016. She is currently pursuing her Masters (LLM) in King's College London. Her interests include privacy and data protection law, human rights, nanotech law and policy and renewable energy law and policy.

Dr Nurul Aini Bani was born in Kuala Lumpur, Malaysia in 1982. She received her MEng degree in electrical engineering from University of Southampton, UK in 2006 and her PhD degree from Universiti Teknologi Malaysia, Malaysia in 2016. Her research interests include polymeric insulation material, space charge measurement, high voltage cable and renewable energy. She is now a lecturer in the Department of Engineering, UTM Razak School of Engineering and Advanced Technology (RSEAT).

Dr Mohd Nabil Muhtazaruddin was born in Mentakab, Pahang, Malaysia in 1985. He obtained his B. Eng. (Hons) in Electrical Engineering (2008) and M. Eng. (2010) in Electrical (Power) from Universiti Teknologi Malaysia (UTM), Johor Bahru, Malaysia. He also received a PhD in 2014 from Shibaura Institute of Technology, Tokyo, Japan. He currently a senior lecturer in Universiti Teknologi Malaysia (UTM) Kuala Lumpur branch under Razak School of Engineering and Advanced Technology. His current research interests include power system optimization, forecasting and renewable energy. 